\title{
Physiological and biochemical changes during the loss of desiccation tolerance in germinating Adenanthera pavonina $\mathrm{L}$. seeds
}

\author{
GIULIANA C.M. SOARES ${ }^{1}$, DENISE C.F.S. DIAS ${ }^{2}$, JOSÉ M.R. FARIA ${ }^{3}$ and EDUARDO E.L. BORGES ${ }^{4}$ \\ ${ }^{1}$ Departamento de Biologia Vegetal, Universidade Federal de Viçosa, Campus Universitário, s/n, 36570-000 Viçosa, MG, Brasil \\ ${ }^{2}$ Departamento de Fitotecnia, Universidade Federal de Viçosa, Campus Universitário, s/n, 36570-000 Viçosa, MG, Brasil \\ ${ }^{3}$ Departamento de Ciências Florestais, Universidade Federal de Lavras, Caixa Postal 3037, 37200-000 Lavras, MG, Brasil \\ ${ }^{4}$ Departamento de Engenharia Florestal, Universidade Federal de Viçosa, \\ Campus Universitário, s/n, 36570-000 Viçosa, MG, Brasil
}

Manuscript received on April 16, 2014; accepted for publication on January 16, 2015

\begin{abstract}
We investigated the loss of desiccation tolerance (DT) in Adenanthera pavonina seeds during germination. Seeds were subjected to imbibition for $0,24,36,48,60$ and $81 \mathrm{~h}$, then dried to their initial moisture content (13\%), rehydrated and evaluated for survival (resumption of growth and development of normal seedlings) and membrane system integrity (electrolyte leakage). Embryonic axes of seeds subjected only to imbibition during the same early time periods were used to investigate the electrophoretic patterns of heat-stable proteins and the relative nuclear DNA content. In A. pavonina seeds, DT remained unchanged until $36 \mathrm{~h}$ of imbibition (resulting in germination and $82 \%$ normal seedlings), after which it was progressively lost, and seeds with a protruded radicle length of $1 \mathrm{~mm}$ did not withstand dehydration. The loss of desiccation tolerance could not be related to either membrane damage caused by drying or the resumption of the cell cycle during germination. However, the decrease in heat-stable protein contents observed throughout germination may be related to the loss of DT in A. pavonina seeds.
\end{abstract}

Key words: cell cycle, desiccation sensitivity, DNA content, drying, heat-stable proteins.

\section{INTRODUCTION}

Desiccation tolerance can be defined as the capacity of seeds to survive and maintain their physiological activities when subjected to a rigorous drying process. Orthodox seeds acquire the ability to tolerate desiccation during the late maturation phase (Bewley 1979). During the deposition of reserves, the moisture content of seeds is gradually reduced, causing a decrease in cell metabolism (Alpert and

Correspondence to: Giuliana Cristina Mourão Soares

E-mail: giulianamourao@hotmail.com
Oliver 2002). During this time, molecular and metabolic changes that enable seeds to be dispersive and render them capable of tolerating long periods of drought are observed (Buitink et al. 2006, Angelovici et al. 2010, Huang and Song 2013).

To prevent or minimize the damage caused by desiccation in orthodox seeds, a series of repair mechanisms are activated, the regulation of which is highly complex (Farrant and Moore 2011, Maia et al. 2011, Gechev et al. 2012, Dinakar and Bartels 2013). Among these mechanisms, the synthesis of protective molecules, such as heat shock proteins 
and late embryogenesis abundant (LEA) proteins, is important (Pammenter and Berjak 1999, Hoekstra et al. 2001). LEA proteins are small hydrophilic, heat-stable molecules synthesized during late maturation in orthodox seeds (Delahaie et al. 2013). They are thought to act as antioxidants and as membrane and protein stabilizers during desiccation of seeds (Tunnacliffe and Wise 2007, Amara et al. 2012),

When orthodox seeds are hydrated and the germination process begins, desiccation tolerance remains unchanged. However, as germination advances, seeds reach a critical stage of imbibition, after which their desiccation tolerance is gradually lost (Hegarty 1988). DNA replication during germination is seen as an important marker of the transition of seeds, from being tolerant to sensitive to desiccation (Osborne and Boubriak 1994, Boubriak et al. 2000).

Several species of economic interest produce recalcitrant seeds, e.g., mango, rubber, cocoa and Paraná pine. Thus, attempts to elucidate the mechanisms related to the sensitivity of seeds to desiccation are essential for defining strategies for the conservation of these species. Studies in recalcitrant seeds are difficult to conduct due to the rapid loss of viability during seed storage. During germination, orthodox seeds develop a recalcitrant behavior (Sun 1999), and they can therefore be used to analyze molecular, metabolic and biochemical events related to sensitivity to desiccation.

In this study, changes in desiccation tolerance were examined in the seeds of Adenanthera pavonina L. during germination. This species belongs to the family Fabaceae-Mimosidae and is arboreal, native to Asia and well-adapted in Brazil (Corrêa 1978). Seeds are produced in large quantities and present orthodox behavior (Rocas 2002). The objective of this study was to investigate whether the loss of desiccation tolerance is associated with the membrane damage caused by drying, with the activation of the cell cycle, or with the levels of heat-stable proteins during germination.

\section{MATERIALS AND METHODS}

PLANT MATERIAL

Seeds of $A$. pavonina $\mathrm{L}$. were extracted from mature fruits collected in June 2011 in Muriaé, Minas Gerais, Brazil (21ㅇ $08^{\prime} \mathrm{S}$; $\left.42^{\circ} 22^{\prime} \mathrm{O}\right)$. After opening the pods, the seeds were collected, processed and stored in a cold room at $5{ }^{\circ} \mathrm{C}$ and $60 \%$ relative humidity $(\mathrm{RH})$ until the beginning of the tests. Immediately following seed processing, the initial moisture content of the seeds was determined.

\section{DORMANCY RELEASE AND SEED GERMINATION}

The tip of the tegument was cut off with pliers in the lateral region opposite the hilum, according to the pre-germinating treatment chosen to break tegument dormancy (Silva et al. 2009). Next, the seeds were immersed in a $5 \%$ Captan $^{\circledR}$ solution for five min, and four replicates of 25 seeds each, were subsequently placed on rolls of paper moistened with distilled water (2.5 times the weight of the dry paper) and incubated in a germinator at $25{ }^{\circ} \mathrm{C}(16$ $\mathrm{h}$ dark/8 h light) (Silva et al. 2009). Germination was assessed daily up to the fifteenth day after sowing. Percentage germination was expressed as the number of normal seedlings developed.

\section{Imbibition curve}

To characterize the pattern of water imbibition by the seeds, two replicates of 12 seeds each were subjected to the pre-germination treatment and maintained under the same germination conditions described above. Then, each seed was individually weighed at regular periods over four days.

\section{MOISTURE CONTENT DETERMINATION}

The moisture content was determined using the oven-drying method at $105{ }^{\circ} \mathrm{C}$ for $24 \mathrm{~h}$, with four replicates of 20 seeds each. The calculation was performed on a fresh weight basis, and the moisture content was expressed as a percentage. 
ASSESSMENT OF THE LOSS OF DESICCATION TOLERANCE DURING GERMINATION

To evaluate the loss of desiccation tolerance during germination, different imbibition times were chosen based on the results obtained from the imbibition curve: 0 (control), 24, 36, 48, 60 and $81 \mathrm{~h}$ (when seeds were germinated with a $1 \mathrm{~mm}$ radicle length).

The seeds were subjected to pre-germination treatment and then sown. After each imbibition period, the seeds were transferred to an elevated screen placed into gerbox-type boxes containing activated silica gel at $20{ }^{\circ} \mathrm{C}$ until returning to their initial moisture content (with the time varying according to each period of the prior imbibition). The drying process was monitored through successive seed weighing, stopping at the point at which the desired seed weight was obtained, indicating the desired moisture content, as determined using the expression proposed by Cromarty et al. (1985). After observing the desired weight, the moisture content was measured to confirm whether the desired moisture content had been reached.

To ensure maintenance of the dry state following drying, after attaining the initial moisture content, the dry seeds were stored in a cold room for $72 \mathrm{~h}$. Then, the seeds were pre-moistened in a humid atmosphere $(100 \% \mathrm{RH})$ at $25^{\circ} \mathrm{C}$ for $24 \mathrm{~h}$ and returned to the early germination conditions. The seeds that reinitiated development and became normal seedlings were considered tolerant to desiccation. The control consisted of fresh seeds, i.e., seeds subjected to pre-germination treatment, but not to the previously mentioned imbibition/ drying process. Four replicates of 25 seeds each per treatment (imbibition times + control), were performed in this study.

\section{ELECTROLYTE LEAKAGE ASSESSMENT}

To analyze the integrity of the membrane system, an electrical conductivity test was performed. The seeds were imbibed for 24, 36, 48, 60 and $81 \mathrm{~h}$, then dried to their initial moisture content and pre-moistened as described above. The control consisted of pre-moistened fresh seeds. The test was performed with four replicates of 25 seeds each per treatment. The samples were weighed and stored in plastic containers with $150 \mathrm{~mL}$ of deionized water for $24 \mathrm{~h}$ at $25{ }^{\circ} \mathrm{C}$ (Hampton and TeKrony 1995). The electrolyte leakage for each solution was determined with an electrical conductivity meter, and the results were expressed as $\mu \mathrm{S} . \mathrm{cm}^{-1} \mathrm{~g}^{-1}$.

\section{DNA CONTENT ASSESSMENT}

Quantification of the nuclear DNA content was conducted via flow cytometry. To this end, the embryonic axes of fresh seeds (control) after imbibition times of 24, 36, 48, 60 and $81 \mathrm{~h}$ were used to prepare nuclear suspensions. Root tips were subjected to nuclear isolation according to the methodology proposed by Carvalho et al. (2008) for subsequent analysis in a Partec PAS II / III flow cytometer (Partec ${ }^{\circledR}$ GmbH, Munster, Germany). To analyze nuclei stained with DAPI (4',6-diamidino2-phenylindole), a high pressure mercury lamp (HBO-100 W) with KG 1, BG 38 and GG 435 filters was used. Each nuclear suspension was processed in the cytometer with at least 5,000 nuclei, and each treatment consisted of three biological replicates (one embryonic axis per replicate).

\section{ELECTROPHORETIC PATTERNS OF HEAT-STABLE PROTEINS}

The analysis of heat-stable proteins was performed using the embryonic axes of fresh seeds (control) and seeds imbibed for 24, 36, 48, 60 and $81 \mathrm{~h}$. Sample preparation and protein extraction were performed according to the methodology proposed by José et al. (2005). A total of $25 \mu \mathrm{L}$ of each sample was subjected to SDS-PAGE (sodium dodecyl sulfate - polyacrylamide gel electrophoresis) using $12.5 \%$ (separating) and at $6 \%$ (concentrating) gels. Electrophoresis was performed at $120 \mathrm{~V}$, and the gels were stained with a $0.05 \%$ Coomassie Brilliant Blue solution (Alfenas 2006) for $12 \mathrm{~h}$, then destained in a solution of $10 \%$ acetic acid. 
DATA ANALYSIS

An entirely randomized experimental design was used in all experiments. The data were subjected to analysis of variance (ANOVA) and Tukey's test at a 5\% probability using Sisvar software, version 5.3.

\section{RESULTS}

\section{SEED GERMINATION AND IMBIBITION}

The A. pavonina seeds had an initial moisture content of approximately $13 \%$, and after breaking tegument dormancy, the mean percentage of germination was $94 \%$.

The imbibition curve (Fig. 1) obtained in this study, showed a slow rate of absorption during the first hours of Phase I, which presented a mean duration of $42 \mathrm{~h}$. The moisture content of the seeds was approximately $55 \%$ at the end of this phase. Then, Phase II began, which lasted for approximately $30 \mathrm{~h}$ and was characterized by the reduced rate of hydration observed in the plateauing of the curve. Visible germination (radicle protrusion) was observed starting at $72 \mathrm{~h}$ of imbibition, after which Phase III began.

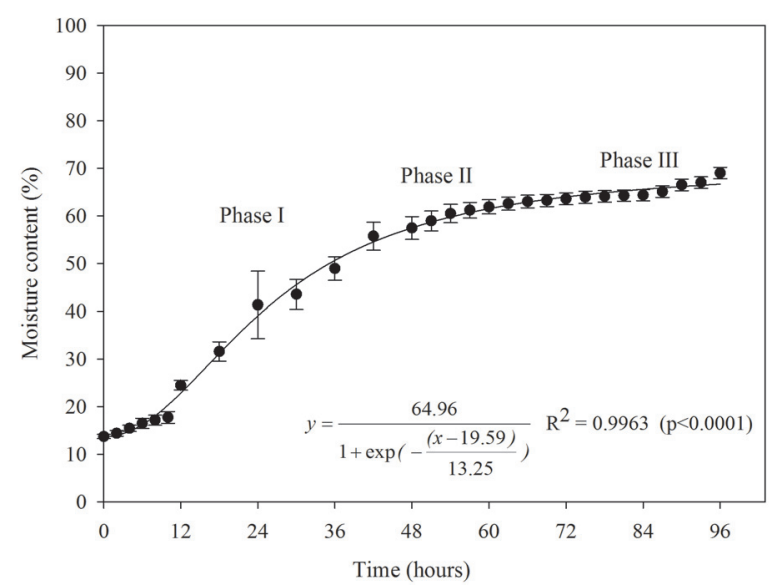

Figure 1 - Changes in moisture content during imbibition of Adenanthera pavonina seeds subjected to pre-germination treatment at $25^{\circ} \mathrm{C}(16 \mathrm{~h}$ dark/ $8 \mathrm{~h}$ light $)$. The bars represent the standard deviation. (Equation adjustment was significant when $\mathrm{p}<0.05)$.
Based on these results, different imbibition times were selected to evaluate the loss of DT during germination: $0,24,36,48,60$ and 81 h of imbibition. The imbibition time of $81 \mathrm{~h}$ was chosen to represent the seeds with $1 \mathrm{~mm}$ primary root because at this time, among the seeds that presented radicle protrusion, $47 \%$ exhibited a $1 \mathrm{~mm}$ primary root length.

LOSS OF DESICCATION TOLERANCE DURING GERMINATION

To determine the point at which DT is lost during germination, seeds were subjected to imbibition for different durations, then dried to their initial moisture content $(13 \%)$, rehydrated and evaluated for survival (development of normal seedlings). The germination values related to the loss of DT are presented in Figure 2. In the early stages of imbibition (24 and $36 \mathrm{~h}$ ), DT remained unchanged. Sensitivity to desiccation became evident after $48 \mathrm{~h}$ of imbibition, as seed survival declined from $82 \%$ to $54.71 \%$ after drying. There was no resumption of growth observed when seeds with a $1 \mathrm{~mm}$ radicle length were dried.

\section{MEMBRAne Damage AsSESSMENT}

The extent of damage caused by drying after different imbibition times was estimated according to the rate of electrolyte leakage from seeds that had been imbibed, dried and pre-moistened (Fig. 2). No significant difference in electrical conductivity was observed between solutions containing fresh seeds and solutions with dry seeds that had been imbibed for $48 \mathrm{~h}$. However, there was a significant increase in electrolyte leakage from seeds imbibed for $60 \mathrm{~h}$ and then dried. The maximum electrical conductivity value was obtained in the solution of seeds with a $1 \mathrm{~mm}$ radicle length that were subsequently dried. 


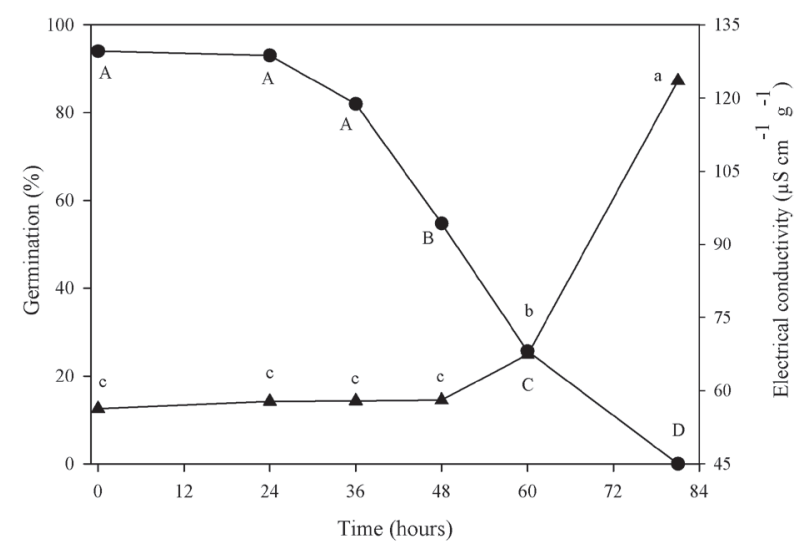

Figure 2 - Electrical conductivity ( $\boldsymbol{\Delta}$ ) and loss of desiccation tolerance $(\bullet)$ in seeds of Adenanthera pavonina subjected to different imbibition times, followed by drying to the initial moisture content. Germination results are expressed as the percentage of normal seedlings obtained after imbibition and drying. Capital letters compare the germination results, and lowercase letters compare the rates of electrical conductivity. Means followed by the same letter do not differ by Tukey's test at a $5 \%$ probability.

\section{NUCLEAR DNA CONTENT}

The flow cytometry analysis of $A$. pavonina radicles revealed that the majority of fresh seed nuclei exhibited a 2C DNA content (77\%), while a small quantity of 4C DNA was present $(5.8 \%)$ (Fig. 3). The DNA contents remained unchanged during the first $60 \mathrm{~h}$ of germination. However, as germination proceeded, a significant increase in the 4C DNA content was observed, while a significant decrease in the 2C DNA content occurred when the roots were $1 \mathrm{~mm}$ in length (approximately 19\%).

\section{ANALYSIS OF HEAT-STABLE PROTEINS}

The relationship of desiccation tolerance to the SDS-gel electrophoretic profile of heat-stable proteins was examined in $A$. pavonina embryonic axes. The analysis was performed with fresh seeds undergoing germination. A set of four heat-stable maturation proteins (Fig. 4, arrows) were consistently present in fresh seeds. This set contained proteins with molecular masses of approximately 98, 96, 66 and $35 \mathrm{kDa}$. Levels of

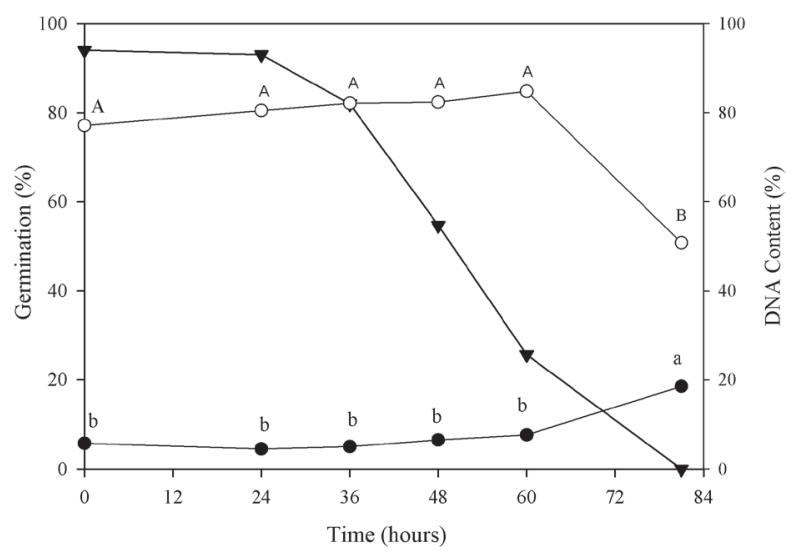

Figure 3 - Contents of 2C (०) and 4C (•) DNA and loss of desiccation tolerance $(\boldsymbol{\nabla})$ in seeds of Adenanthera pavonina during and after germination. Germination results are expressed as the percentage of normal seedlings obtained after the treatment of seeds with different imbibition times, followed by drying to the initial moisture content. Capital letters compare the contents of 2C DNA, and lowercase letters compare the contents of 4C DNA. Means followed by the same letter do not differ by Tukey's test at a $5 \%$ probability.

these heat-stable proteins declined after $24 \mathrm{~h}$ of imbibition, which remained stable until $36 \mathrm{~h}$ of imbibition. After $48 \mathrm{~h}$, the contents of the 98,96 and $66 \mathrm{kDa}$ fractions decreased, and after $60 \mathrm{~h}$ of imbibition, these fractions decreased sharply, as did the $35 \mathrm{kDa}$ fraction. Only traces of the 66 and 35 $\mathrm{kDa}$ fractions were detected in seeds with a $1 \mathrm{~mm}$ radicle length.

\section{DISCUSSION}

As imbibition progressed, drying of $A$. pavonina seeds to the initial moisture content $(13 \%)$ caused a decrease in the survival rate of the seeds (Fig. 2 ). This indicates that the mechanisms related to the maintenance of tolerance to desiccation were inactivated with the progress of the germination process, contributing to an increase in the sensitivity of the seeds to desiccation.

According to Bewley and Black (1994), desiccation tolerance in seeds decreases during Phases I and II of imbibition and is lost during or after Phase III. This observation agrees with the 


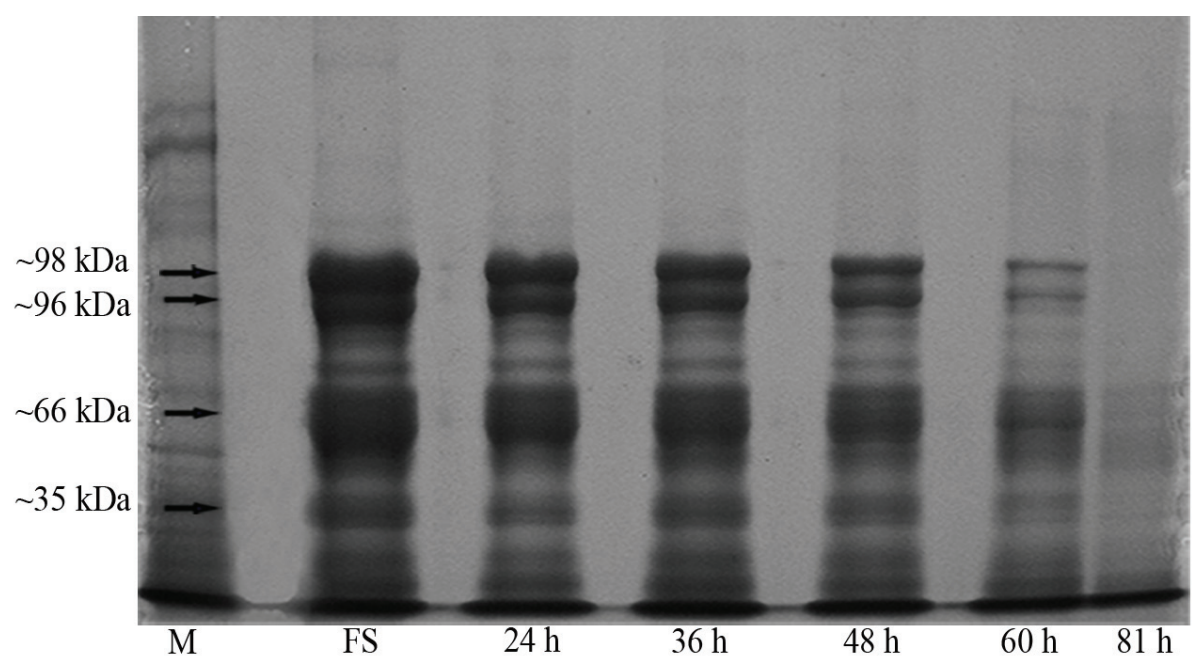

Figure 4 - Electrophoretic pattern of heat-stable proteins in the embryonic axes of Adenanthera pavonina seeds. M - molecular marker. FS - fresh seeds. 24-60 h - seeds im-bibed for 24, 36, 48 and $60 \mathrm{~h} .81 \mathrm{~h}$ - seeds with a radicle $1 \mathrm{~mm}$ in length.

results obtained for the seeds of $A$. pavonina, as loss of tolerance to desiccation was observed $48 \mathrm{~h}$ after imbibition, i.e., during the transition between Phases I and II. In some species, sensitivity to desiccation is evident when the seeds are in a more advanced metabolic stage, i.e., the transition between Phases II and III, as observed in the seeds of Glycine max and Zea mays (Koster and Leopold 1988), Pisum sativum (Reisdorph and Koster 1999), Triticum aestivum (Miazek et al. 2001) and Peltophorum dubium (Guimarães et al. 2011).

The ability to tolerate desiccation is known to vary among seed tissues (Kermode and FinchSavage 2002). According to Buitink et al. (2003), the radicle is the first structure to become sensitive to desiccation. In some species, however, this structure remains tolerant, only becoming sensitive with an increase in length. In the seeds of tomato (Lin et al. 1998) and Medicago truncatula (Faria et al. 2005), for example, loss of tolerance to desiccation occurs at the point at which the primary roots reach $2 \mathrm{~mm}$ in length. In the present study, no seed with $1 \mathrm{~mm}$ radicle survived after the drying process was performed. However, it was not possible to determine whether tolerance to dessication was lost in seeds with primary roots smaller than $1 \mathrm{~mm}$ because they were not evaluated in this study.

Cellular membranes are particularly vulnerable to damage caused by desiccation. During the drying of seeds, accumulation of reactive oxygen species and free radicals is observed in cells (Leprince et al. 1994, Ntuli et al. 2011), resulting from the rupture of plastids and from the electron transport system of the mitochondria (Pammenter and Berjak 1999). These compounds can damage proteins, lipids and nucleic acids, causing permanent damage to enzymes, chromosomes and membranes. Lipid peroxidation reduces the fluidity of cell membranes, interfering with their selective permeability during rehydration (Walters et al. 2002).

Thus, the integrity of membranes is crucial to maintain the viability of seeds (Kermode and Finch-Savage 2002). For this reason, orthodox seeds are dispersed with mechanisms that attempt to minimize the damage caused by desiccation. Among these mechanisms, it has been suggested that the accumulation of sucrose and oligosaccharides of the raffinose family (raffinose, stachyose and verbascose) can reduce the harmful 
effects of desiccation on cell membranes (Hoekstra et al. 2001, Buitink et al. 2002). During desiccation, these sugars are inserted into the polar regions of the lipid bilayer, maintaining the proper spacing of the lipid groups and the structure of the membrane (Walters et al. 2002, Vicré et al. 2004).

Evaluation of electrolyte leakage from seeds of $A$. pavonina via electrical conductivity was performed to investigate whether the loss of desiccation tolerance is associated with possible damage to the membrane caused by drying, since previously, the relationship between desiccation tolerance and the integrity and stability of seed membranes has been reported (Corbineau et al. 2004, Koster and Leopold 1988, Spanò et al. 2011). In the present study, sensitivity to desiccation was evident after $48 \mathrm{~h}$ of imbibition. However, the increased rate of electrolyte leakage observed in the seeds indicated that drying caused damage to cell membranes only after $60 \mathrm{~h}$ of imbibition. Although an increase in electrical conductivity corresponds to a loss of tolerance to desiccation in the seeds of pea (Reisdorph and Koster 1999, Koster et al. 2003), canola (Bagniewska-Zadwoma 2008) and Phaleria macrocarpa (Ahmed Asrity et al. 2013), it is likely that in the present work, the electrical conductivity test tended to overestimate the ability of seeds to tolerate desiccation.

It has been suggested that the loss of tolerance to desiccation during germination coincides with the level of activity of the embryonic cells of seeds, mainly at the root tip (Osborne et al. 2002). Radicle growth is initially driven by the cell expansion process. Subsequently, usually after radicle protrusion, cell division begins (Bewley and Black 1994). Interphase, the stage that precedes cell division, is divided into three phases: $G_{1}$ (pre-synthesis), S (DNA synthesis) and $\mathrm{G}_{2}$ (postsynthesis). Cells with a $2 \mathrm{C}$ nuclear DNA content are found in $\mathrm{G}_{1}$ phase, while cells with a $4 \mathrm{C}$ DNA content are observed in $\mathrm{G}_{2}$ phase. The $\mathrm{C}$ constant is the nuclear DNA content for the haploid condition.
The cytometric analysis revealed that the radicles of the fresh seeds of $A$. pavonina exhibited a high relative $2 \mathrm{C}$ DNA content (Fig. 3). This suggests that the majority of cells were retained in $G_{1}$ phase, while a small number were in $G_{2}$ phase of the cellular cycle. This is a prevalent characteristic in orthodox seeds (Bino et al. 1993, Castro et al. 2000, Vázquez-Ramos and Sánchez 2003, Gendreau et al. 2008), although there are reports of dispersed orthodox seeds with high 4C DNA contents (approximately 40\%) (Faria et al. 2005, Guimarães et al. 2011). High 2C DNA contents have also been observed in the mature seeds of intermediate and recalcitrant species, such as Castanea sativa (Bino et al. 1993), Inga vera (Faria et al. 2004) and Coffea arabica (Silva et al. 2008), indicating that the relationship between tolerance to desiccation and events inherent to the cellular cycle, is weak.

The low 4C DNA contents found in fresh seeds may be explained by the effects of desiccation during the late maturation process in orthodox seeds. According to Deltour and Barsy (1985), the moisture content of embryonic cells declines rapidly when seeds are dehydrated, and metabolism is consequently reduced, while cytoplasmic viscosity is increased, precluding the formation of the complex structures necessary for the activity of the cell cycle.

Resumption of the cell cycle was demonstrated by the increased 4C DNA and reduced 2C DNA contents observed at $60 \mathrm{~h}$ after germination. However, in the seeds of A. pavonina, loss of tolerance to desiccation was initially observed after $48 \mathrm{~h}$ of imbibition; i.e., the development of sensitivity to desiccation preceded the activation of cellular division. Although it has been proposed that cells with a 4C DNA content are more sensitive to stress conditions because they are more vulnerable to factors inducing mutation (Deltour and Barsy 1985, Sliwinska 2009), cells with a 2C DNA content have been shown to be sensitive to 
desiccation in the seeds of A. pavonina, Medicago truncatula (Faria et al. 2005) and Peltophorum dubium (Guimarães et al. 2011).

Orthodox seeds also accumulate proteins as a mechanism for repairing the damage caused by desiccation, including LEA proteins. One feature of LEA proteins is their hydrophilicity and high proportion of charged amino acids, which contribute to their heat and acid stability (Amara et al. 2012). In general, they are considered to contribute to diverse protective mechanisms upon desiccation: replacement of water, stabilization of macromolecules and cellular structures, ion sequestration and membrane integrity maintenance, alone or in combination with sugars (Hoekstra et al. 2001, Tunnacliffe and Wise 2007, Battaglia et al. 2012).

Studies show that the synthesis of LEA proteins, coincides with the acquisition of desiccation tolerance during the development of seeds in Ricinus communis (Han et al. 1997), Arabidopsis thaliana (Bies et al. 1998), Prunus amygdalus (Campalans et al. 2000), Glycine max (Samarah et al. 2006) and Nelumbo nucifera (ShenMiller et al. 2013). In addition, the disappearance of LEA proteins and heat-stable proteins, was related with loss of desiccation tolerance in radicles of M. truncatula (Boudet et al. 2006) and seeds of soybean (Blackman et al. 1991), respectively.

Here we tested the hypothesis that heat-stable maturation proteins are associated with desiccation tolerance in Adenanthera pavonina seeds. The emergence and development of sensitivity to desiccation after $48 \mathrm{~h}$ of imbibition, coincided with the reduction of heat-stable protein contents in A. pavonina seeds (Fig. 4). Our data indicate that heat-stable maturation proteins somehow play an important role in seed-water interactions, protecting seeds against the damage caused by desiccation. It is known that the maintenance of the ability to tolerate desiccation, depends on the joint and integrated action of the various repair mechanisms in seeds. The lack or inefficiency of one or more protection mechanisms determines the degree of sensitivity to desiccation in different species (Berjak and Pammenter 2013).

Considering all of the physiological events analyzed in this study, only the reduction of heatstable protein contents can be related to the loss of tolerance to desiccation in the seeds of Adenanthera pavonina.

\section{ACKNOWLEDGMENTS}

The authors thank Dr. Carlos Roberto de Carvalho (UFV) for his assistance with the flow cytometry analysis and the Coordenação de Aperfeiçoamento de Pessoal de Nível Superior (CAPES) for financial support.

\section{RESUMO}

Nós investigamos a perda da tolerância à dessecação (TD) em sementes de Adenanthera pavonina durante a germinação. Sementes submetidas à embebição por 0 , $24,36,48,60$ e $81 \mathrm{~h}$ foram secas até à umidade inicial (13\%), reidratadas e avaliadas quanto à sobrevivência (retomada do crescimento e formação de plântulas normais) e à integridade do sistema de membranas (extravasamento de eletrólitos). Eixos embrionários de sementes submetidas apenas à embebição, pelos mesmos tempos citados anteriormente, foram utilizados para avaliar os padrões eletroforéticos de proteínas resistentes ao calor e o conteúdo relativo de DNA nuclear. Em sementes de A. pavonina, a TD foi mantida por até $36 \mathrm{~h}$ de embebição (resultando em germinação e $82 \%$ de plântulas normais), após o que foi gradativamente perdida, até que sementes com $1 \mathrm{~mm}$ de raiz primária não sobreviveram após a secagem. A perda da TD não pôde ser correlacionada com danos causados por secagem ao sistema de membranas, nem com a retomada do ciclo celular durante a germinação. No entanto, a redução do conteúdo de proteínas resistentes ao calor, ao longo da germinação, pode estar relacionada com a perda da TD em sementes de $A$. pavonina.

Palavras-chave: ciclo celular, sensibilidade à dessecação, conteúdo de DNA, secagem, proteínas resistentes ao calor. 


\section{REFERENCES}

AHMED ASRITY SM, TSAN FY, SYED OMAR SR AND DING P. 2013. Desiccation tolerance in Phaleria macrocarpa seeds. Acta Hort 1012: 1401-1405.

ALFENAS AC. 2006. Eletroforese e marcadores bioquímicos em plantas e microrganismos, $2^{\mathrm{a}}$ ed., Viçosa; UFV, $627 \mathrm{p}$.

ALPERT P AND OLIVER MJ. 2002. Drying without dying. In: Black M and Pritchard HM (Eds), Desiccation and survival in plants: drying without dying, Wallingford: CABI Publishing, Wallingford, UK, p. 3-43.

AMARA I, ODENA A, OLIVEIRA E, MORENO A, MASMOUdi K, PAGÈS M AND GONDAV A. 2012. Insights into maize LEA proteins: from proteomics to functional approaches. Plant Cell Physiol 53: 312-329.

ANGElOVICI R, GALILI G, FERNIE AR AND FAIT A. 2010. Seed desiccation: a bridge between maturation and germination. Trends Plant Sci 15: 211-218.

BAGNIEWSKA-ZADWOMA A. 2008. The root microtubule cytoskeleton and cell cycle analysis through desiccation of Brassica napus seedlings. Protoplasma 233: 177-185.

Battaglia M, OlVERA-CARrillo, Garciarrubio A, CAMPOS F AND COVARRUBIAS AA. 2012. The enigmatic LEA proteins and other hydrophilins. Plant Physiol 148: 6-24.

BERJAK P AND PAMMENTER NW. 2013. Implications of the lack of desiccation tolerance in recalcitrant seeds. Front Plant Sci 4: 1-9.

BEWLEY JD. 1979. Physiological aspects of desiccation tolerance. Annu Rev Plant Physiol 30: 195-238.

BEWLEY JD AND BLACK M. 1994. Physiology of development and germination, $2^{\text {nd }}$ ed., New York: Plenum Press, $445 \mathrm{p}$.

Bies N, Aspart L, CARLES C, Gallois P AND DELSENY M. 1998. Accumulation and degradation of Em proteins in Arabidopsis thaliana: evidence for post-transcriptional controls. J Exp Bot 47: 161-169.

BINO RJ, LANTERI S, VERHOEVEN HA AND KRAAK HL. 1993. Flow cytometric determination of nuclear replication stage in seed tissues. Ann Bot 72: 181-187.

BLACKMAN SA, WetTlaufER SH, OBENDORF RL AND LEOPOLD AC. 1991. Maturation proteins associated with desiccation tolerance in soybean. Plant Physiol 96: 868874.

BOUbRIAK I, Dini M, BERJAK P AND OSBORNE D. 2000. Desiccation and survival in the recalcitrant seeds of Avicennia marina: DNA replication, DNA repair and protein synthesis. Seed Sci Res 10: 307-315.

BOUDET J, BUITINK J, HOEKSTRA FA, ROGNIAUX H, LARRÉ C, SATOUR P AND LePrince O. 2006. Comparative analysis of the heat stable proteome of radicles of Medicago truncatula seeds during germination identifies late embryogenesis abundant proteins associated with desiccation tolerance. Plant Physiol 140: 1418-1436.

BUitink J, HoEKSTRA FA AND LEPRINCE O. 2002. Biochemistry and biophysics of tolerance systems.
In: Black M and Pritchard HM (Eds), Desiccation and survival in plants: drying without dying, Wallingford: CABI Publishing, Wallingford, UK, p. 293-318.

BUITINK J ET AL. 2006. Transcriptome profiling uncovers metabolic and regulatory processes occurring during the transition from desiccation sensitive to desiccation-tolerant stages in Medicago truncatula seeds. Plant J 47: 735-750.

BUITINK J, Vu BL, SATOUR P AND LEPRINCE O. 2003. The re-establishment of desiccation tolerance in germinated radicles of Medicago truncatula Gaertn. Seeds. Seed Sci Res 13: 273-286.

Campalans A, Pages M and Messeguer R. 2000. Protein analysis during almond embryo development. Identification and characterization of a late embryogenesis abundant protein. Plant Physiol Bioch 38: 449-457.

CARVAlHo CR, Clarindo WR, PRAÇA MM, ARAúJo FS AND CARELS N. 2008. Genome size, base composition and karyotype of Jatropha curcas L., an important biofuel plant. Plant Sci 174: 613-617.

CASTRO RD, VAN LAMMEREN AAM, GROOT SPC, BINO RJ AND HILHORST HWM. 2000. Cell division and subsequent radicle protrusion in tomato seeds are inhibited by osmotic stress but DNA synthesis and formation of microtubular cytoskeleton are not. Plant Physiol 122: 327-335.

CORBINEAU F, BERJAK P, PAMMENTER N, VINEL D, PICARD MA AND CÔME D. 2004. Reversible cellular and metabolic changes induced by dehydration in desiccation-tolerant wheat seedling shoots. Physiol Plantarum 122: 28-38.

CORRÊA MP. 1978. Dicionário das plantas úteis do Brasil e das exóticas cultivadas, Rio de Janeiro: Imprensa Nacional, $307 \mathrm{p}$.

CROMARTY AS, ELLIS RH AND ROBERTS EH. 1985. Design of seed storage facilities for genetic conservation, Roma: IPGRI, $100 \mathrm{p}$.

Delahaie J, Hundertmark M, Bove J, Leprince O, ROGNIAUX H AND BUITINK J. 2013. LEA polypeptide profiling of recalcitrant and orthodox legume seeds reveals ABI3-regulated LEA protein abundance linked to desiccation tolerance. J Exp Bot 64: 4559-4573.

DELTOUR R AND BARSY T. 1985. Nuclear activiation during early germination of the higher plant embryo. J Cell Sci 75: 43-83.

DINAKAR C AND BARTELS D. 2013. Desiccation tolerance in resurrection plants: new insights from transcriptome, proteome, and metabolome analysis. Front. Plant Sci 4: $1-14$.

FARIA JMR, BUITINK J, VAN LAMMEREN AAM AND HILHORST HWM. 2005. Changes in DNA and microtubules during loss and re-establishment of desiccation tolerance in germinating Medicago truncatula seeds. J Exp Bot 56: 2119-2130.

FARIA JMR, VAN LAMMEREN AAM AND HILHORST HWM. 2004. Desiccation sensitivity and cell cycle aspects in seeds of Inga vera subsp. affinis. Seed Sci Res 14: 165178. 
FARRANT JM AND MOORE JP. 2011. Programming desiccation-tolerance: from plants to seeds to resurrection plants. Curr Opin Plant Biol 14: 340-345.

GeChEV TS, DINAKAR C, BENINA M, TONEVA V AND BARTELS D. 2012. Molecular mechanisms of desiccation tolerance in resurrection plants. Cell Mol Life Sci 69: 3175-3186.

Gendreau E, Romaniello S, BARAD S, LEYMARIE J, BENECH-ARNOLD R AND CORBINEAU F. 2008. Regulation of cell cycle activity in the embryo of barley seeds during germination as related to grain hydration. J Exp Bot 59: 203-212.

GUIMARÃES CC, FARIA JMR, OLIVEIRA JM AND SILVA EAA. 2011. Evaluation of the loss of desiccation tolerance and nuclear DNA content in sedes of Peltophorum dubium (Spreng.) Taubert during and after germination. Rev Bras sementes 33: 207-215.

HAMPTON JG AND TEKRONY DM. 1995. Handbook of vigour test methods, $3^{\text {rd }}$ ed., Zurich: ISTA - International Seed Testing Association, $117 \mathrm{p}$.

Han B, Hughes DW, Galau GA, BeWley JD AND KERMODE AR. 1997. Changes in late-embryogenesisabudant (LEA) messenger RNAs and dehydrins during maturation and premature drying of Ricinus comunis L. seeds. Planta 201: 27-35.

HEGARTY TW. 1988. The physiology of seed hydration and dehydration, and the relation between water stress and the control of germination: a review. Plant Cell Environ 1: 101-119.

Hoekstra FA, Golovina EA AND Buitink J. 2001. Mechanisms of plant desiccation tolerance. Trends Plant Sci 6: 431-438.

HUANG H AND SONG S. 2013. Change in desiccation tolerance of maize embryos during development and germination at different water potential PEG-6000 in relation to oxidative process. Plant Physiol Biochem 68: 61-70.

JOSÉ SCBR, VON PINHO EVR, VON PINHO RG AND SILVEIRA CM. 2005. Electrophorectic pattern of the heat resistant proteins of corn seeds. Pesq Agropec Bras 40: 115-121.

KERMODE AR AND FINCH-SAVAGE BE. 2002. Desiccation sensitivity in orthodox and recal-citrant seeds in relation to development. In: Black M and Pritchard HM (Eds), Desiccation and survival in plants: drying without dying, Wallingford: CABI Publishing, Wallingford, UK, p. 149184.

KOSTER KL AND LEOPOLD AC. 1988. Sugars and desiccation tolerance in seeds. Plant Physiol 88: 829-832.

KOSTER KL, REISDORPH N AND RAMSAY JL. 2003. Changing desiccation tolerance of pea embryo protoplasts during germination. J Exp Bot 54: 1607-1614.

LEPRINCE O, ATHERTON NM, DELTOUR R AND HENDRY GAF. 1994. The involvement of respiration in free radical processes during loss of desiccation tolerance in germinating Zea mays L. Plant Physiol 104: 1333-1339.

LIN TP, YEN WL AND CHIEN CT. 1998. Disappearance of desiccation tolerance of imbibed crop seeds is not associated with the decline of oligosaccharides. J Exp Bot 49: 1203-1212.

MAIA J, DEKKERS BJW, PROVART NJ, LigTERINK W AND HILHORST HWM. 2011. The re-establishment of desiccation tolerance in germinated Arabidopsis thaliana seeds and its associated transcriptome. PLoS ONE 6: e29123.

MiaZEK A, Bogdan J AND ZAGDANSKA B. 2001. Effects of water during germination of wheat seeds. Biol Plantarum 44: 397-403.

NTULI TM, FINCH-SAVAGE WE, BERJAK P AND PAMMENTER NW. 2011. Increased drying rate lowers the critical water content for survival in embryonic axes of english oak (Quercus robur L.) seeds. J Integr Plant Biol 53: 270-280.

OSBORNE DJ AND BOUBRIAK II. 1994. DNA and desiccation tolerance. Seed Sci Res 4:175-185.

OSBORNE DJ, BOUBRIAK I AND LEPRINCE O. 2002. Rehydration of dried systems: membranes and the nuclear genome. In: Black M and Pritchard HM (Eds), Desiccation and survival in plants: drying without dying, Wallingford: CABI Publishing, Wallingford, UK, p. 343-364.

PAMMENTER NW AND BERJAK P. 1999. A review of recalcitrant seed physiology in relation to desiccation tolerance mechanisms. Seed Sci Res 9: 13-37.

REISDORPH NA AND KOSTER K. 1999. Progressive loss of desiccation tolerance in germinating pea (Pisum sativum) seeds. Physiol Plantarum 105: 266-271.

ROCAS NA. 2002. Adenanthera pavonina L. In Vozzo JA Tropical tree seed manual - Part II, Species descriptions (A to C). Agriculture Handbook 721, U.S. Dept. of Agriculture/Forest Service. Available in: http://www.rngr.net/ publications.

SAMARAH NH, MUllen RE, CIANZIO SR AND SCOTT P. 2006. Dehydrin-like proteins in soybean seeds in response to drought stress during seed filling. Crop Sci 46: 21412150.

SHEN-Miller J, LindNER P, XIE Y, Villa S, WOODING K, ClARKE SG, LOO RRO AND LOO JA. 2013. Thermalstable proteins of fruit of long-living sacred lotus Nelumbo nucifera Gaertn var. China Antique. Tropical Plant Biol 6: 69-84.

Silva AIS, CORTE VB, PEREIRA MD, CuZzUOL GRF AND LEITE ITA. 2009. Effect of temperature and pregerminative treatments in the germination of Adenanthera pavonina L seeds. Semina: Ci Agr 30: 815-824.

SILVA EA, TOOROP PE, VAN LAMMEREN AAM AND HilHoRst HWM. 2008. ABA inhibits embryo cell expansion and early cell division events during coffee 
(Coffea arabica 'Rubi') seed germination. Ann Bot 102: 1-9.

SLIWINSKA E. 2009. Nuclear DNA replication and seed quality. Seed Sci Rese 19: 15-25.

SPANÒ C, BotTegA S, GRILLI I AND LORENZI R. 2011. Responses to desiccation injury in developing wheat embryos from naturally and artificially dried grains. Plant Physiol Bioch 49: 363-367.

SUN WQ. 1999. Desiccation sensitivity of recalcitrant seeds and germinated orthodox seeds: can germinated orthodox seeds serve as a model system for studies of recalcitrance? In Proceedings of IUFRO Seed Symposium 1998: Recalcitrant Seeds. Kuala Lumpur, Malaysia: FRIM, Malaysia, p. 29-42.
TUNNACLIFFE A AND WISE MJ. 2007. The continuing conundrum of the LEA proteins. Naturwissenschaften 94: 791-812.

VÁZQUEZ-RAMOS JM AND SÁNCHEZ MP. 2003. The cell cycle and seed germination. Seed Sci Res 13: 113-130.

VICRÉ M, FARRANT JM AND DRIOUICH A. 2004. Insights into the cellular mechanisms of desiccation tolerance among angiosperm resurrection plant species. Plant Cell Environ 27: 1329-1340.

WALTERS C, FARRANT JM, PAMMENTER NW AND BERJAK P. 2002. Desiccation stress and damage. In: Black M and Pritchard HM (Eds), Desiccation and survival in plants: drying without dying, Wallingford: CABI Publishing, Wallingford, UK, p. 263-291. 
